\title{
Functionality of the Criminal Justice System: A research programme in Bergen 2011 - 2018
}

\author{
ANNE MARIE FRøSETH \& LINDA GRÖNING *
}

The research project 'Functionality of the Criminal Justice System' has concluded after a project period of six years, from 1 June 2011 to 1 October 2018. The project, which has been based at the Faculty of Law at the University of Bergen, is the largest research project on criminal law and criminal justice in Norway to date. It has been possible thanks to generous funding from Trond Mohn through Bergen Research Foundation. The project has been led by Professor Anne Marie Frøseth and Professor Linda Gröning, both professors at the Faculty of Law, University of Bergen. The project has also involved five senior researchers/postdocs: Ragnar Auglend, Johan Boucht, Gert Johan Kjelby, Annika Suominen and Rasmus Wandall; two PhD students: Marte Habberstad Mo and Katrine Holter; and three master's students (60 ECTS credits): Mia Abrahamsen, Stine Borge and Charlotte Evjen Helgesen. The project has been supported by an international advisory board, consisting of Professor Sabine Gless (Basel University), Professor Thomas Elholm (Copenhagen University) and Professor Dan Frände (Helsinki University).

The following is a brief report on the overall aims, methodological framework and achievements of the project. ${ }^{1}$

* Linda Gröning, Professor, Faculty of Law, University of Bergen, and Researcher, Regional Competence Centre for Research and Education in Forensic Psychiatry and Psychology, Haukeland University Hospital of Bergen. Anne Marie Frøseth, Professor, Faculty of Law, University of Bergen.

1 For further information about the project, see https://www.uib.no/prosjekt/srf [last accessed 30 January 2019].

This is an Open-access article distributed under the terms of the Creative Commons Attribution 3.0 Unported License (http://creativecommons.org/licenses/ by/3.0/), permitting all use, distribution, and reproduction in any medium, provided the original work is properly cited. 


\section{The overall aim and focus of the project}

The project 'Functionality of the Criminal Justice System' has been anchored in a larger theoretical framework that has been developed at the law faculty, and has interacted closely with other research projects. ${ }^{2}$ In adding to the legal theoretical aspects explored in these projects, the Functionality project has explored the functional dimension of the criminal justice system, with particular focus on police law and criminal procedure. The project has, in this regard, also laid the foundation for a new, large research project in police law and criminal procedure, which will be carried out from March 2017 till 28 February 2023. ${ }^{3}$

More specifically, the aim of the project 'Functionality of the Criminal Justice System' has been to contribute to a deeper understanding of the functional premises for the different norms, concepts and institutional practices of the system. The research strategy has been to concentrate on certain specific topics/areas following how the criminal justice system is organised: the fundamental aims and prerequisites for a criminal justice system; legislation; the police and prosecution service; the procedure in courts; the correctional service; and the interfaces between these institutions and the public. Through the individual projects, the overall project has also contributed to a deeper understanding of the criminal justice system as a functioning whole, as well as to new insights into specific aspects of the system. With regard to this, the project and the different individual research projects have been designed to reflect all central aspects of the system-its conceptual foundation; its key functions of legislation, investigation and judgment; its central rule systems of police law, criminal law, criminal procedure, and administrative law; etc. The project has also integrated research on the interaction between the criminal justice system and other areas of law, such as tort law, mental health law, and constitutional law, in addition to developments in EU criminal law and its interaction with national criminal law. Another aim of the research project has been to bring these research perspectives to bear practically; to make an impact on how the different actors in the system could work to improve strategies, priorities and communication between different sectors.

2 Criminal Law Theory: A New Norwegian Approach (concluded), funded by Bergen Research Foundation, led by Jørn Jacobsen, and Theory in Practice: Risks and Responses in Modern Criminal Law (concluded), funded by the Norwegian Research Council, led by Linda Gröning and Jørn Jacobsen.

3 Politi og Påtalerett, funded by Bergen Research Foundation, led by Gert Johan Kjelby. See https:// www.uib.no/politiogpatalerett [last accessed 30 January 2019]. 


\section{The overarching framework: functionality as a methodological per- spective}

The premise of the functionality of the criminal justice system has served as the normative and methodological framework for the project. Functionality, in this context, refers to the quality of being functional, in relation to the ability of something to perform a given task or function, or to fulfil a given purpose. As such, the concept of functionality has, in the legal context, clear links to (practical) usefulness, efficiency and utility. It evokes the idea that the law responds to society's needs, and thereby appears to be generally attractive. At the same time, it seems clear that the argument of functionality, at least from the perspective of criminal law science, has certain limitations.

As a basic starting point, the criminal justice system can be understood through its function of exercising penal power. The system is characterised by its function of delivering and implementing different kinds of authoritative decisions concerning crime and punishment. Here, the project takes as its point of departure that the basic premise of functionality is essentially twofold: efficient crime control and efficient control of state power. However, in order to contribute to the fulfilment of its basic functions, the criminal justice system must perform a multitude of different, more specific tasks at different institutional levels.

How, then, should functionality be understood more specifically in the criminal justice system? And how should the functional argument govern the content and development of the system? What, if any, functionality requirements govern (or should govern) the rules for police investigations of crime; the distinction and coordination between police power and military power; the freedom of discretion of the public prosecutor; the possibility of confiscating stolen goods; or the construction of criminal intent? And how should functionality requirements interact with the general principles of criminal law, as limitations on penal power? What, more generally, are the limitations on arguments of functionality in the criminal justice system? These kinds of questions have been central to the development of the project and the different individual research projects within it. For instance, we have explored the rules for preventive detention, the role of the child welfare services in the fight against crimes of domestic violence against children, and the limits of police power. In order to tie different insights together, we have also looked at the premises of the criminal justice system as a whole. The project has, in this regard, developed a systemic perspective on the meaning of functionality.

More specifically, the project has been based on the insight that it is important to study different dimensions of the criminal justice system, such as general criminal law, police law, criminal procedure, and the law concerning the execution of sentences, in 
light of the systematic relationships between them. The functionality of one area of law typically depends on the rules and practices within another area.

At the beginning of the project period, the researchers paid special attention to fundamental issues in the criminal justice system, and the meaning of functionality in this context. In 2011, an international symposium was held on the 'Fundamentals of Criminal Law' in collaboration with another research project on criminal Law at the Faculty of Law, University of Bergen: 'Criminal Law Theory: A New Norwegian Approach' (for a report and contributions from the symposium, see Nordisk Tidsskrift for Kriminalvidenskab no 1,2012$)$.

In 2012, the project held a workshop on the more theoretical aspects of the functionality dimension, with the topic: 'Functionality as a Research Aim in Legal Research Across Disciplines.' The aim of the workshop was to achieve a deeper understanding of the overall goal of the research project, and how the participating researchers could operationalise different aspects of the functionality dimension in their individual projects.

\section{Interaction with practitioners as a method for gaining and imple- menting knowledge}

With its thematic focus on functionality, the project has devoted much of its attention to the perspective of the agencies of the criminal justice system, and to how the system works in practice. In order to gain insights into the functional premises of different research topics, the project has engaged in dialogue with key practitioners in the system and made use of their knowledge. Through such dialogue, the project has also communicated the scientific perspective to them, and in this way contributed to a more enlightened practice.

This dialogue has also given the ongoing research an opportunity to respond to real needs and challenges relating to the lack of functionality in the system. To some extent, these challenges have been articulated for the first time during the dialogues the project has initiated. This way of collaborating with practitioners contributed to the development of new dimensions in legal research methodology, based on our special focus on understanding the rules in light of their functional and systematic context.

The project has facilitated this dialogue through various workshops and conferences throughout the project period, to which we have invited central representatives of different institutions in the criminal justice system. At these workshops and conferences, we have focused on more specific problems and aspects of the functionality of the criminal justice system. The research questions have been elaborated on in relation to certain topics, and some of the practitioners have participated in two or three research activities 
and given us feedback over time. One feature of the project's work method has been to prepare for workshops by distributing a questionnaire to the participants in advance to encourage independent contributions from practitioners and to get feedback from them on an academic contribution or result.

In 2012, the project organised a conference on 'Domestic Violence at the Interface between Criminal Law and the Law on Child Welfare' (for a report from the conference, see Tidsskrift for Strafferett no. 1, 2013), with central representatives from the police, prosecution authorities and child welfare services in attendance. The conference focused on functional coordination of the different sets of rules and the different perspectives these agencies have as result of their different purposes and priorities.

In 2014, we held a workshop on the topic of the 'Public Sense of Justice', and its significance for the criminal justice system. The participants were representatives from all parts of the criminal justice system, in addition to some distinguished researchers from the Faculty of Law. The workshop, and the ongoing dialogue it generated among the participants, resulted in the anthology Rettsfølelsen i strafferettssystemet: perspektiver fra teori og praksis, Anne Marie Frøseth, Linda Gröning \& Rasmus H. Wandall, eds., Gyldendal 2016 (ISBN: 978-82-0548-952-3).

In October 2015, we organised a conference on 'Police Law and Criminal Procedure'. The aim of this conference was to communicate insights from our research to central practitioners in the field, and at the same time to discuss different topics in light of their practical experience. The conference gathered 100 participants, among which were representatives from all parts of the criminal justice system, and in particular from the police and prosecution services.

In 2016, we held a workshop together with the Ministry of Justice on the topic: 'Premises for and Obstacles to the Interaction of Actors in the Criminal Justice System', with particular emphasis on the information flow between the actors. The participants were representatives of the police, the National Criminal Investigation Service, the National Authority for Investigation and Prosecution of Economic and Environmental Crime in Norway, the National Police Directorate, the Public Prosecutor's Office, defence lawyers, the courts, the Ministry of Justice, and the Norwegian Correctional Service.

Finally, in August 2018, we held our concluding workshop, which focused specifically on our two $\mathrm{PhD}$ projects about preventive detention and criminal intent.

At all of these workshops and conferences, we have gained valuable insights through facilitated discussions between the different actors in the criminal justice system. The practitioners have shown great interest and worked hard on their contributions to the project. As far as we know, some of the participants have also made use of insights from the research activities in their own policy discussions. In this regard, our project has 
succeeded in making an ongoing impact on practice through direct dialogue with these actors.

\section{Interdisciplinarity as an overall research ambition}

In order to achieve deeper knowledge of the different dimensions of the project, we have not only communicated with practitioners, but have also had interdisciplinary research cooperation as a general aim. By integrating particular empirical perspectives, the project has aimed to discuss the system in a way that goes beyond the conventional distinctions between different legal areas and research disciplines, in order to arrive at functional and adequate normative and institutional solutions. In this connection, one of our senior researchers, Rasmus Wandall, carried out a research project in Ethiopia based on empirical data. It gives legal science new insights into the influence and importance of the sociological dimensions of functionality in the criminal justice system, see 'Trust and Legal Governance, Journal of Law and Society, 2/2015, pp. 283-307.

Other members of the project have collaborated with researchers within the fields of psychology, medicine, criminology, philosophy, and economics. Both our PhD candidates integrate perspectives external to law: Katrine Rong Holter is developing her PhD thesis in light of philosophical perspectives on intent. Marte Habberstad Mo is integrating different perspectives on risk (from psychology, for example) in her PhD-thesis on preventive detention. Several of the publications produced by the project reflect such an interdisciplinary approach. We have also held several workshops aimed at facilitating interdisciplinary cooperation.

\section{Overview of the results and achievements}

- Scientific publications. During the project period, we have published a high number of articles and books.

- Presentation of papers at seminars. The researchers in the project have presented their work at national or international conferences and workshops, and thereby contributed to the ongoing discussion in their respective research fields.

- Contributions in the media. Several of the members of the project have been active in the media, writing in-depth pieces, giving interviews, etc.

- Organisation of seminars, workshops and conferences. As described, an important aspect of the communication strategy for the project has been to organise different kinds of seminars, workshops, and conferences. 
- Education. The project has devoted attention to research-based education. We have involved master's students in the project. They have all written a master's thesis (60 ECTS credits). Furthermore, through Gert Johan Kjelby and Ragnar Auglend, the project has focused on education in police law and criminal procedure. Finally, the research done in the project has led to the writing of several books on criminal law and criminal procedure. In co-authorship with Jørn Jacobsen and Erling Johannes Husabø, Linda Gröning has written Frihet, Forbrytelse og straff - en systematisk fremstilling av norsk strafferett (Fagbokforlaget, 2016) and Gert Johan Kjelby has written a textbook on criminal prosecution (Cappelen Damm Akademisk 2017). 